\title{
PENGARUH KEBIJAKAN DIVIDEN DAN KEBIJAKAN HUTANG TERHADAP NILAI PERUSAHAAN (Studi Empiris Pada Perusahaan LQ45 di BEI Periode 2012-2015)
}

\author{
Oleh \\ Desy Septariani \\ Dosen Program Studi Pendidikan Ekonomi \\ Fakultas Ilmu Pendidikan dan Pengetahuan Sosial \\ Universitas Indraprasta PGRI \\ Email: \\ desy.septa@gmail.com
}

\begin{abstract}
ABSTRAK
Penelitian ini bertujuan untuk mengetahui pengaruh kebijakan dividen yang diukur dari dividend payout ratio dan kebijakan hutang yang diukur dari debt to equity ratio terhadap nilai perusahaan yang diukur dari Price to book value pada perusahaan LQ45 yang terdaftar di BEI periode 2012-2015. Populasi dari penelitian semua perusahaan yang terdaftar di BEI. Teknik pengambilan sampel dalam penelitian ini adalah purposive sampling dengan jumlah sampel 45 perusahaan $L Q 45$ yang terdaftar di BEI periode 20122015. Metode analisis data yang digunakan adalah regresi linear berganda. Hasil penelitian secara parsial debt to equity ratio mempunyai pengaruh yang signifikan terhadap Price to book value dan dividend payout ratio tidak berpengaruh secara signifikan terhadap Price to book value. Secara simultan dividend payout ratio dan Debt to equity ratio berpengaruh terhadap Price to book value.
\end{abstract}

Kata Kunci : Kebijakan Dividen, Kebijakan Hutang, Nilai Perusahaan 


\section{A. PENDAHULUAN}

Perusahaan didirikan tentunya memiliki suatu tujuan yang jelas. Tujuan yang ingin dicapai sebuah perusahaan dapat berupa tujuan jangka pendek dan tujuan jangka panjang. Tujuan jangka pendek yang ingin dicapai oleh perusahaan adalah memperoleh laba yang maksimal dengan sumber daya yang dimiliki, sedangkan tujuan jangka panjang perusahaan adalah meningkatkan nilai perusahaan. Nilai perusahaan dapat menunjukkan nilai aset yang dimiliki perusahaan seperti surat-surat berharga. Nilai perusahaan sangat penting, karena mencerminkan kinerja perusahaan yang dapat mempengaruhi persepsi investor terhadap perusahaan. Nilai perusahaan akan menujukkan kemakmuran pemegang saham. Dengan semakin tinggi nilai perusahaan, maka semakin sejahtera para shareholdernya (Fenandar dan Raharja, 2012). Jadi apabila nilai perusahaan tinggi, berarti kemakmuran pemegang saham juga tinggi. Perusahaan yang ingin mencapai tujuan jangka panjang akan mengambil beberapa keputusan dalam perusahaannya (Husnan dan Pujiastuti, 2006 dalam Noviana, 2016).

Nilai perusahaan dipengaruhi oleh faktor internal dari perusahaan yang berupa kebijakan dividen, kebijakan hutang, profitabilitas dan keputusan investasi. Faktor-faktor ini sering digunakan oleh calon investor dalam menilai kemampuan perusahaan dalam usahanya meningkatkan nilai perusahaan (Abdillah, 2013)

Kebijakan dividen (Dividen Policy) merupakan keputusan apakah laba yang diperoleh perusahaan pada akhir tahun akan dibagi kepada pemegang saham dalam bentuk dividen atau akan ditahan untuk menambah modal guna pembiayaan investasi dimasa yang akan datang (Harjito dan Martono, 2011). Keputusan membagikan dividen sering menjadi masalah yang dihadapi oleh sebuah perusahaan. Dividen merupakan alasan bagi investor untuk menginvestasikan modal yang dimiliki, karena dividen merupakan pengembalian yang akan diterima atas investasi yang ditanamkan pada perusahaan. Dividen yang diharapkan oleh investor memiliki tujuan utama untuk meningkatkan kesejahteraannya, sedangkan perusahaan mengharapkan pertumbuhan secara terus menerus untuk mempertahankan kelangsungan hidup serta memberikan kesejahteraan kepada pemegang saham.

Kebijakan dividen dalam penelitian ini diproksikan dengan Dividend Payout Ratio (DPR). DPR diukur dengan membandingkan dividen kas per lembar saham terhadap laba yang diperoleh per lembar saham (Marlina dan Danica, 2009).

Kebijakan hutang merupakan kebijakan yang dilakukan perusahaan untuk mendanai operasi dengan menggunakan hutang keuangan atau yang biasa disebut financial leverage (Brigham dan Houston, 2007 dalam Fatimah, 2015). Perusahaan dengan penggunaan tingkat hutang yang lebih tinggi dapat meningkatkan laba per lembar saham, yang nantinya akan meningkatkan harga saham perusahaan yang berarti juga meningkatnya nilai perusahaan tersebut.

Hutang merupakan sumber pendanaan eksternal perusahaan untuk menjalankan kegiatan operasionalnya. Penggunaan hutang bagi perusahaan memiliki pengaruh yang sensitif terhadap tinggi rendahnya nilai perusahaan. 
Semakin tinggi proporsi hutang yang ditetapkan perusahaan pada tingkat tertentu, maka semakin tinggi nilai perusahaan. Jika tingkat hutang melebihi proporsi hutang yang ditetapkan oleh perusahaan, maka nilai perusahaan akan turun, karena manfaat yang diperoleh dari penggunaan hutang relatif kecil daripada biaya yang ditimbulkannya.

Penelitian tentang kebijakan dividen, leverage, profitabilitas terhadap nilai perusahaan sebelumnya sudah dilakukan oleh Rehulina dan Handoyo (2014). Hasil penelitiannya dividend payout ratio berpengaruh positif terhadap nilai perusahaan dan leverage berpengaruh negatif dan signifikan terhadap nilai perusahaan. Penelitian Abdillah (2013) tentang kebijakan dividen, hutang, profitabilitas dan keputusan investasi terhadap nilai perusahaan menghasilkan bahwa dividend payout ratio (DPR) tidak memiliki pengaruh yang signifikan terhadap price to book value $(P B V)$ sedangkan debt to equity ratio (DER) memiliki pengaruh yang positif dan signifikan terhadap price to book value (PBV). Perbedaan ini dapat dikarenakan oleh pemilihan sampel dan tahun laporan keuangan yang berbeda. Dari penjelasan di atas, maka penelitian ini akan membahas tentang Pengaruh Kebijakan Dividen dan Kebijakan Hutang terhadap Nilai Perusahaan Pada Perusahaan LQ45 yang terdaftar di BEI.

\section{B. KAJIAN PUSTAKA}

\section{Kebijakan Dividen}

Dividen adalah pembayaran bagian laba perusahaan kepada pemegang saham. Sebuah perusahaan tidak harus membagikan dividen kepada pemegang saham, tetapi jika investor membeli saham dengan tujuan untuk mendapatkan dividen dan perusahaan tidak membayarkan dividennya, maka saham yang dimilikinya dapat mereka jual. Apabila jumlah saham yang dijual terlalu banyak, akan menyebabkan nilai saham mengalami penurunan.

Kebijakan dividen merupakan keputusan untuk menentukan seberapa besar bagian laba yang akan dibagikan kepada pemegang saham dan yang akan ditahan dalam perusahaan untuk dijadikan investasi kembali. Semakin besar dividen yang dibayarkan, maka laba ditahan semakin sedikit, akibatnya pertumbuhan perusahaan menjadi lambat. Sebaliknya semakin besar laba yang ditahan untuk pertumbuhan perusahaan, berarti laba yang dibagikan sebagai dividen semakin kecil. Persentase pendapatan/laba yang akan dibayarkan kepada pemegang saham sebagai kas dividen disebut dividend payout ratio atau DPR (Warsini, 2003 dalam Rehulina dan Handoyo, 2014). Indikator dividen yang digunakan sebagai alat ukur dalam perusahaan dapat berupa dividend yield dan dividend payout ratio (DPR).

Dalam penelitian ini proksi yang digunakan untuk mengukur dividen adalah Dividend payout ratio (DPR), karena dividend payout ratio mencerminkan presentase dari setiap rupiah yang dihasilkan dibagikan kepada pemilik dalam bentuk tunai, yang dihitung dengan membagi dividen kas per saham dengan laba per saham. Dividend payout ratio sangat berkaitan dengan kinerja keuangan perusahaan. Jika kinerja keuangan perusahaan bagus, makan perusahaan mampu menetapkan besarnya dividend payout ratio sesuai dengan harapan pemegang 
saham, tanpa mengabaikan kepentingan perusahaan untuk sehat dan tumbuh. Besar kecilnya dividend payout ratio akan mempengaruhi keputusan investasi para pemegang saham dan juga berpengaruh pada kondisi keuangan perusahaan. Dengan melihat dividend payout ratio ini, dapat diketahui apakah dividend perusahaan yang dibagikan kepada investor lebih baik dari pada perusahaan lain. Dividend payout ratio (DPR) dihitung dengan rumus Dividend Per Share/Earning Per Share atau dividen per lembar saham dibagi laba per lembar saham.

\section{Kebijakan Hutang}

Hutang merupakan salah satu sumber pembiayanaan eksternal yang digunakan oleh perusahaan untuk membiayai kebutuhan dananya. Pengertian hutang menurut Munawir (2004) adalah semua kewajiban keuangan perusahaan kepada pihak lain yang belum terpenuhi, dimana hutang ini merupakan sumber dana atau modal perusahaan yang berasal dari kreditor.

Kebijakan hutang termasuk kebijakan pendanaan perusahaan yang bersumber dari eksternal (Rahmawati \& Haryanto, 2011). Sebagian perusahaan menganggap bahwa penggunaan hutang dirasa lebih aman daripada menerbitkan saham baru. Semakin tinggi kebijakan hutang yang dilakukan, maka akan semakin tinggi nilai perusahaan. Kebijakan hutang berkaitan erat dengan struktur modal karena hutang merupakan salah satu komposisi dalam struktur modal (Sukirni, 2012).

Dalam penelitian ini kebijakan hutang diproksikan dengan debt to equity ratio (DER), karena DER merupakan rasio yang tepat digunakan untuk menjukkan kemampuan perusahaan membayar semua kewajiban jangka panjang dan jangka pendek. Semakin besar rasio ini menjukkan semakin besar kewajibannya dan rasio yang semakin rendah mencerminkan semakin tinggi kemampuan perusahaan dalam memenuhi kewajiban (Sumantri dan Candraningrat, 2013). Jadi Jika DER meningkat menunjukkan kinerja perusahaan semakin memburuk. DER yang tinggi menujukkan struktur permodalan lebih banyak dibiayai oleh pinjaman sehingga ketergantungan perusahaan terhadap kreditor meningkat, apabila perusahaan memperoleh laba maka akan diserap untuk melunasi hutang dan akhirnya laba yang dibagikan kepada pemegang saham akan semakin kecil yang berakibat investor enggan membeli saham perusahaan tersebut, sehingga nilai perusahaan akan turun (Dharmastuti, 2005 dalam Yuniati, Raharjo dan Oemar, 2016). Nilai DER dihitung dengan menggunakan rumus Total hutang/jumlah modal sendiri.

\section{Nilai Perusahaan}

Pengeluaran investasi memberikan sinyal yang positif dari investasi kepada manajer mengenai pertumbuhan perusahaan pada masa yang akan datang, sehingga dapat meningkatkan harga saham sebagai indikator dari nilai perusahaan. Harga saham yang tinggi akan membuat nilai suatu perusahaan juga tinggi (Brealeys et al, 2007). Indikator yang dapat digunakan untuk mengukur nilai perusahaan adalah Price earning ratio (PER), Tobin's Q, Price To Book Value (PBV). 
Nilai perusahaan merupakan persepsi investor terhadap perusahaan yang dikaitkan dengan harga saham perusahaan tersebut. Sujoko dan Soebiantoro (2007), menjelaskan bahwa nilai perusahaan merupakan persepsi investor terhadap tingkat keberhasilan perusahaan yang sering dikaitkan dengan harga saham. Dalam penelitian ini variabel nilai perusahaan diwakili oleh price to book value (PBV), karena PBV banyak digunakan dalam pengambilan keputusan investasi. PBV menggambarkan seberapa besar pasar menghargai nilai buku saham suatu perusahaan. Perusahaan yang berjalan dengan baik umumnya memiliki PBV di atas satu, yang mencerminkan bahwa nilai pasar saham lebih besar dari nilai bukunya.

Menurut Rehulina dan Wibisono (2014), PBV memiliki beberapa keuanggulan yaitu pertama, nilai buku merupakan ukuran yang stabil dan sederhana yang dapat dibandingkan dengan harga pasar. Kedua, PBV dapat dibandingkan antar perusahaan sejenis untuk menunjukkan apakah murah atau mahal harga saham. PBV dapat memberikan gambaran pergerakan harga suatu saham, sehingga dari gambaran tersebut secara tidak langsung PBV memberikan pengaruh terhadap harga saham. Nilai PBV diperoleh dengan rumus Membagi Market Price dengan Book value per share atau harga pasar per lembar saham dibagi harga buku per lembar saham.

\section{METODE PENELITIAN}

Tempat penelitian berada di Bursa Efek Indonesia di jakarta dengan cara mengunjungi website http://www.idx.co.id dan dari Indonesia Capital Market Directory (ICMD) pada perusahaan LQ45 yang telah mempublikasikan laporan keuangan tahunannya.Waktu pengambilan data dalam penelitian ini dilakukan dari tahun 2012 sampai tahun 2015. Populasi dalam penelitian ini adalah semua perusahaan yang terdaftar di Bursa Efek Indonesia (BEI) periode 2012 sampai 2015, Sedangkan sampel penelitian adalah Perusahaan LQ45dengan jumlah 45 perusahaan. Metode pengambilan sampelnya purposive sampling. Data yang digunakan dalam penelitian ini adalah data sekunder, yaitu berupa laporan keuangan. Metode Pengumpulan data dalam penelitian ini adalah metode dokumentasi.Metode analisis data yang digunakan adalah analisis regresi linear berganda.

\section{HASIL DAN PEMBAHASAN}

\section{Uji Normalitas}

Uji normalitas bertujuan untuk menguji apakah dalam model regresi, variabel terikat dan variabel bebas keduanya berdistribusi normal atau tidak. Model regresi yang baik adalah data berdistribusi normal atau mendekati normal. Untuk melihat normalitas data dapat dilakukan dengan melihat histogram dan normal probabilitas plot. Dari hasil pengujian normalitas data dapat disimpulkan bahwa data yang digunakan berdistribusi normal. Hal ini terlihat dari histogram dimana poligon kecendrungan tidak menceng kekiri atau kekanan, serta titik-titik pada probability plotnya menyebar di garis diagonal. 


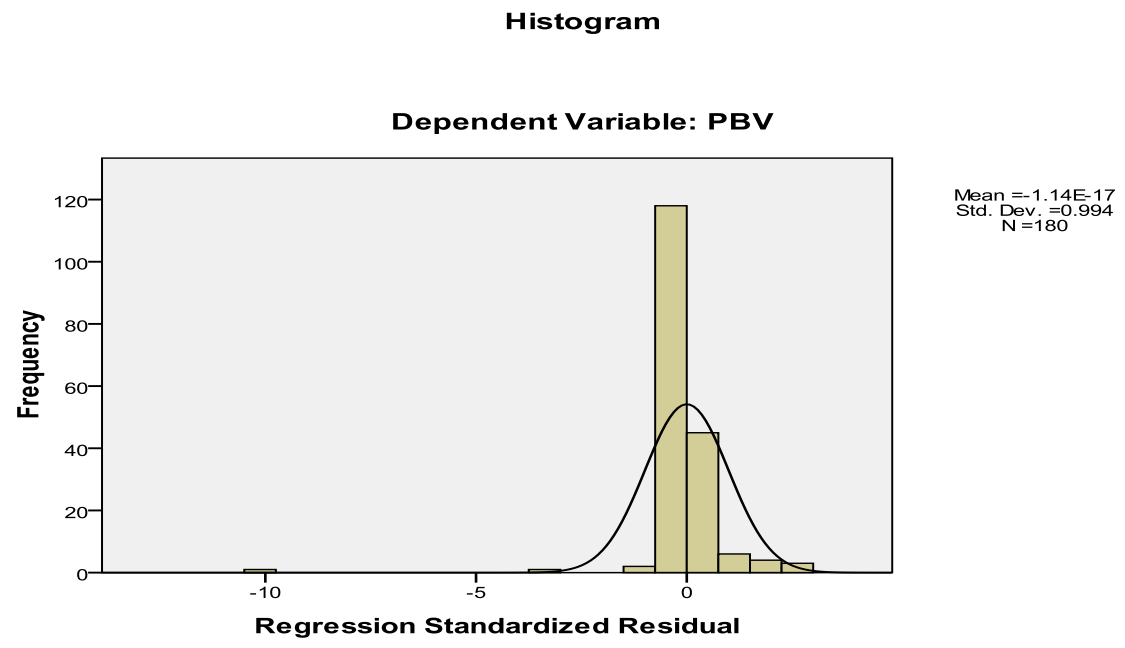

Gambar 1.

Histogram

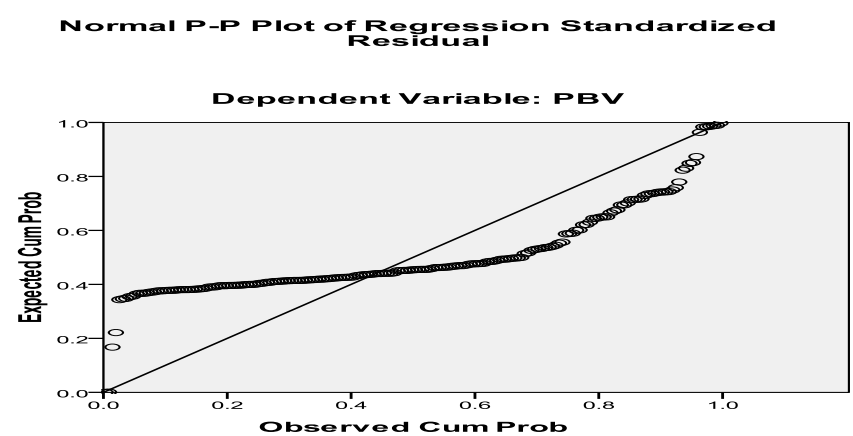

Gambar 2.

P-P Plot

\section{Uji Multikolinearitas}

Uji multikolinearitas ini digunakan untuk mengetahui ada tidak adanya hubungan yang berarti antara masing-masing variabel independen dalam model regresi. Model regresi yang baik adalah variabel independen dalam model tidak berkorelasi secara sempurna. Salah satu cara untuk mengetahui adanya multikolinearitas adalah dengan melakukan uji Varian Inflation Factor (VIP). Apabila nilai VIP tidak lebih dari 10 dan nilai Tolerance tidak kurang dari 0,1 maka model dikatakan terbebas dari multikolinearita. Dari hasil pengujian diperoleh bahwa semua varibel memiliki nilai tolerance diatas 0,1 dan nilai VIP nya dibawah 10 . Dengan demikian dalam model ini maka tidak ada masalah multikolinearitas. 
Tabel 1.

Uji Multikolinearitas Coefficients $^{\mathrm{a}}$

\begin{tabular}{|l|r|r|}
\hline \multirow{2}{*}{ Model } & \multicolumn{2}{|c|}{ Collinearity Statistics } \\
\cline { 2 - 3 } & Tolerance & \multicolumn{1}{c|}{ VIF } \\
\hline 1(Constant) & & \\
DPR & .985 & 1.015 \\
DER & .985 & 1.015 \\
\hline
\end{tabular}

a. Dependent Variable: PBV

\section{Uji Autokorelasi}

Pengujian ini bertujuan untuk mengetahui ada tidaknya korelasi atau hubungan antar data yang diurutkan berdasarkan waktu. Untuk mendeteksi adanya autokorelasi dalam suatu model regresi digunakan metode Durbin Watson. Menurut Singgih Santoso (2008), untuk melihat ada tidaknya gejala autokorelasi, data yang digunakan haruslah data yang rangkaian masa. Syarat tidak terjadinya autokorelasi adalah $-2<\mathrm{dw}<2$. Autokolerasi tidak terjadi apabila angka D-W berada diantara -2 sampai +2 . jika angka $\mathrm{D}-\mathrm{W}$ dibawah -2 berarti ada autokolerasi positif dan jika angka D-W diatas +2 berarti ada autokolerasi negatif. Dari penelitian yang telah dilakukan nilai Durbin Watson 1,494 dimana nilai tersebut berada diantara -2 sampai +2 , maka dapat disimpulkan bahwa tidak terjadinya autokorelasi pada penelitian ini.

Tabel 2.

\section{Uji Autokorelasi}

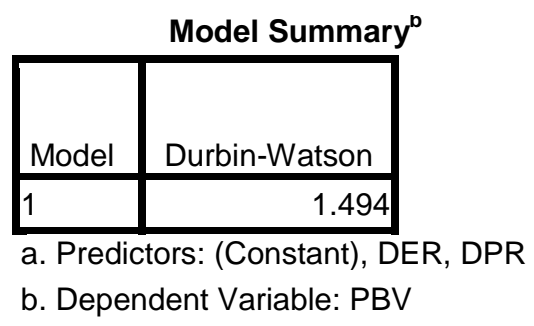

\section{Uji Heteroskedastisitas}

Uji ini bertujuan untuk menguji apakah dalam sebuah model regresi, terjadi ketidaksamaan varians dari residual satu pengamatan kepengamatan yang lain. Adanya heteroskedastisitas dapat dilihat dari grafik yang membentuk pola tertentu atau teratur (bergelombang, menyebar, menyempit). Jika tidak ada pola yang jelas, titik-titik menyebar di atas dan dibawah angka 0 pada sumbu Y, maka tidak terjadi heteroskedastisitas.Dengan melihat grafik scatterplott, terlihat titiktitik menyebar secara acak, serta tersebar baik di atas maupun di bawah angka 0 pada sumbu Y, maka dapat diambil kesimpulan bahwa tidak terdapat heteroskedastisitas pada model regresi yang digunakan. 


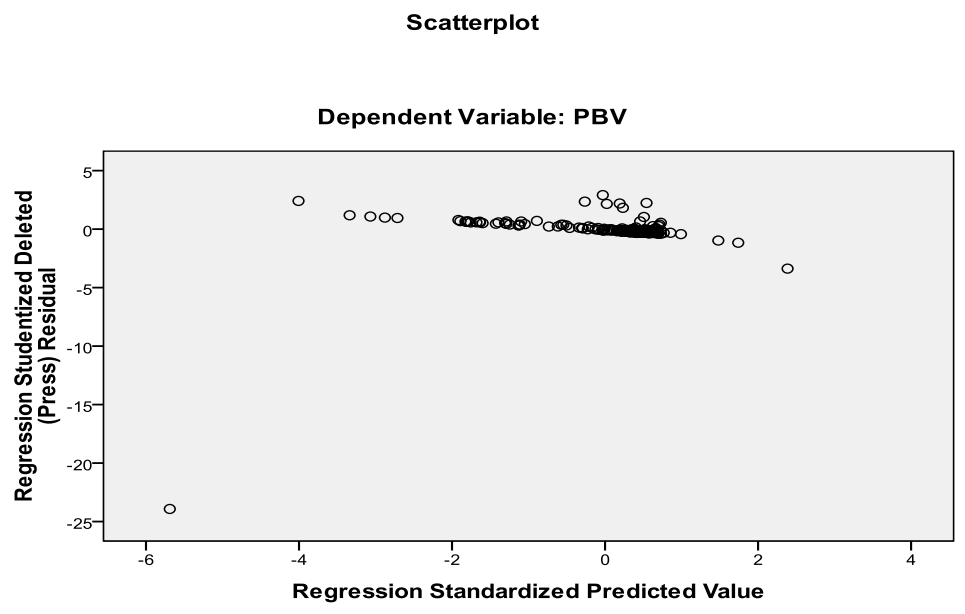

Gambar 3.

Scatterplot

\section{Analisis Regresi Berganda}

Berdasarkan output program SPSS secara parsial pengaruh dari variabel independen yaitu, Dividend Payout Ratio (DPR), dan Debt To Equity Ratio (DER)terhadap Price To Book Value (PBV), dapat didisusun persamaan regresi linear berganda sebagai berikut:

$$
\mathrm{Y}=8,136+0,024 \mathrm{DPR}-2,570 \mathrm{DER}
$$

Tabel 3.

Hasil Regresi Linear Berganda

\begin{tabular}{|c|c|c|c|c|c|c|}
\hline \multicolumn{7}{|c|}{ Coefficients $^{a}$} \\
\hline \multirow{2}{*}{\multicolumn{2}{|c|}{ Model }} & \multicolumn{2}{|c|}{ Unstandardized Coefficients } & \multirow{2}{*}{$\begin{array}{c}\text { Standardized } \\
\text { Coefficients }\end{array}$} & \multirow[b]{2}{*}{$\mathrm{T}$} & \multirow[b]{2}{*}{ Sig. } \\
\hline & & $\mathrm{B}$ & Std. Error & & & \\
\hline \multirow[t]{3}{*}{1} & (Constant) & 8.136 & 2.140 & & 3.802 & .000 \\
\hline & DPR & .024 & .033 & .051 & .727 & .468 \\
\hline & DER & -2.570 & .520 & -.350 & -4.946 & .000 \\
\hline
\end{tabular}

a. Dependent Variable: PBV

\section{Uji Goodness Of Fit}

Ketepatan fungsi regresi sampel dalam menaksir nilai aktual dapat diukur dari goodness of fitnya. Secara statistik, hal ini dapat diukur dari nilai statistik t, nilai statistik F, dan koefisien determinasinya ( $\mathrm{R}$ square/ $\mathrm{R}^{2}$ ). Koefisien determinasi dipergunakan untuk mengukur seberapa jauh kemampuan model dalam menerangkan variasi variabel dependen. Nilai koefisien determinansi ini diantara nol dan satu. Nilai $\mathrm{R}^{2}$ yang kecil berarti kemampuan variabel-variabel independen dalam menjelaskan variabel dependen sangat terbatas. Dari hasil perhitungan diperoleh nilai $\mathrm{R}$ Square nya sebesar $0.129(12,9 \%)$ hal ini 
menunjukkan bahwa nilai perusahaan yang diproksikan oleh $P B V$ dapat dijelaskan oleh variabel DPR dan DER 12,9\%, sedangkan sisanya $87,1 \%$ dipengaruhi oleh faktor-faktor lain yang tidak dijelaskan dalam penelitian ini.

Tabel 4.

Hasil Pengujian Goodness of fit

Model Summary ${ }^{\mathrm{D}}$

\begin{tabular}{|l|r|r|r|c|}
\hline Model & $\mathrm{R}$ & R Square & \multicolumn{1}{c|}{$\begin{array}{c}\text { Adjusted R } \\
\text { Square }\end{array}$} & $\begin{array}{c}\text { Std. Error of the } \\
\text { Estimate }\end{array}$ \\
\hline 1 & $.359^{\mathrm{a}}$ & .129 & .119 & 19.39077 \\
\hline
\end{tabular}

a. Predictors: (Constant), DER, DPR

b. Dependent Variable: PBV

\section{Uji F}

Uji $\mathrm{F}$ digunakan untuk mengetahui apakah semua variabel independen mempunyai pengaruh secara bersama-sama terhadap variabel dependen. Jika $F$ hitung $>\mathrm{F}$ tabel , maka $\mathrm{H}_{\mathrm{O}}$ ditolak. Apabila $\mathrm{F}$ hitung $<\mathrm{F}$ tabel, maka Ho diterima. Ha diterima: $\rho<0,05$ Ho ditolak Ha ditolak: $\rho>0,05$ Ho diterima.Dari hasil regresi dapat diketahui secara bersama-sama variabel independen memiliki pengaruh yang signifikan terhadap variabel dependen. Hal ini dibuktikan dari nilai F hitung 13,122 lebih besar dari F tabel 3,04 (13,122 > 3,04) dengan (df =2 dan 177) dengan nilai signifikan sebesar 0.000 . Karena probabilitas jauh lebih kecil dari 0,05 atau 5\%, maka model regresi dapat digunakan untuk memprediksi Price To Book Value (PBV) atau Variabel DPR dan DER secara bersama-sama (simultan) berpengaruh signifikan terhadap PBV, dan dapat mendukung $\mathrm{R}^{2}$ (goodness of fit).

\section{Tabel 5.}

\section{Hasil Uji F}

ANOVA $^{\mathrm{D}}$

\begin{tabular}{|ll|r|r|r|r|r|}
\hline Model & & Sum of Squares & Df & Mean Square & F & \multicolumn{1}{c|}{ Sig. } \\
\hline 1 & Regression & 9868.034 & 2 & 4934.017 & 13.122 & $.000^{a}$ \\
& Residual & 66552.362 & 177 & 376.002 & & \\
& Total & 76420.396 & 179 & & & \\
\hline
\end{tabular}

a. Predictors: (Constant), DER, DPR

b. Dependent Variable: PBV

\section{Uji t}

Uji $\mathrm{t}$ bertujuan untuk menunjukkan seberapa jauh pengaruh variabel independen secara individual dapat menerangkan variabel dependen. Ha diterima: $\rho<0,05$ Ho ditolak. Ha ditolak: $\rho>0,05$ Ho diterima. Jika t hit $>$ t tabel, Ho ditolak, sedangkan Jika $t$ hitung $<\mathrm{t}$ tabel, Ho diterima. Dari hasil analisis regresi 
variabel independen debt to equity ratio (DER $=\mathrm{X} 2)$, berpengaruh negatif dan signifikan terhadap variabel price to book value (PBV), dengan tingkat signifikan $0.000(0,000<0,05)$, Sedangkan variabel dividend payout ratio $(\mathrm{DPR}=\mathrm{X} 1)$ tidak berpengaruh terhadap Variabel price to book value $(P B V)$, karena nilai signifikannya 0,468 lebih besar dari tingkat signifikan $0,05(0,468>0,05)$.

\section{Pembahasan}

Hipotesis Pertama menyatakan bahwa Dividend Payout Ratio-DPR (X1) mempunyai pengaruh terhadap Price To Book Value $(P B V)$. Berdasarkan hasil penelitian diperoleh koefisien regresi DPR 0,024 , nilai $t$ hitungnya bertanda positif sebesar 0,727 dengan nilai signifikannya 0.468 dimana lebih besar dari $0,05(0,468>0,05)$, berarti hipotesis Pertama $(\mathrm{H} 1)$ ditolak dimana dividend payout ratio tidak mempunyai pengaruh terhadap price to book value. Hasil penelitian ini sesuai dengan teori dividen irrelevan Miller dan Modigliani (MM) dalam Abdillah (2013:4) yang menyatakan bahwa kebijakan dividen bersifat irrelevan, yang berarti tidak memiliki pengaruh terhadap nilai perusahaan. Penelitian ini sejalan dengan penelitian yang dilakukan oleh Abdillah (2013) yang menyatakan bahwa divident payout ratio tidak memiliki pengaruh yang signifikan terhadap price to book value. Penelitian ini juga sejalan dengan penelitian yang dilakukan oleh Septia (2015), dimana dividen payout ratio tidak berpengaruh terhadap priceto book value pada perusahaan manufaktur yang terdaftar di BEI periode 2011-2013.

Hipotesis kedua menyatakan bahwa Debt To Equity Ratio -DER (X2) mempunyai pengaruh terhadap Price To Book Value. Berdasarkan penelitian diperoleh koefisien regresi DER sebesar -2,570, nilai t hitung bertanda negatif sebesar -4,946, dengan nilai signifikannya 0,000 di mana lebih kecil dari 0,05 $(0,000<0,05)$, berarti hipotesis kedua $(\mathrm{H} 2)$ diterima dimana debt to equity ratio (X2) mempunyai pengaruh negatif dan signifikan terhadap price to book value. Dengan kata lain jika nilai debt to equity ratio (DER) menurun maka nilai price to book value (PBV) mengalami kenaikan. Penelitian ini sejalan dengan penelitian yang dilakukan oleh Rehulina dan Handoyo (2014) yang menyatakan bahwa leverage berpengaruh negatif dan signifikan terhadap nilai perusahaan yang diproksikan oleh price to book value pada perusahaan manufaktur yang terdaftar di BEI periode 2009-2013. Penelitian ini juga sejalan dengan penelitian yang dilakukan oleh Yuniati, Raharjo dan Oemar (2016), dimana debt to equity ratio berpengaruh terhadap price to book value pada perusahaan manufaktur yang terdaftar di BEI periode 2009-2014. 


\section{E. SIMPULAN}

Berdasarkan hasil analisis yang telah dilakukan pada perusahaan LQ45 periode 2012 sampai 2015 di BEI, dapat diambil kesimpulan sebagai berikut:

a) Variabel independen Dividend Payout Ratio (DPR) danDebt To Equity Ratio (DER), secara simultan (bersama-sama) berpengaruh signifikan terhadap Price To Book Value (PBV).

b) Secara parsial faktor yang berpengaruh signifikan terhadap Price To Book Value (PBV) adalah Debt To Equity Ratio (DER), Sedangkan variabel Dividend Payout Ratio (DPR)tidak berpengaruh secara signifikan terhadap Price To Book Value (PBV). 


\section{DAFTAR PUSTAKA}

Abdillah, Ardianto. (2013). Analisis Pengaruh Kebijakan Dividen, Kebijakan Hutang, Profitabilitas dan Keputusan Investasi Terhadap Nilai Perusahaan Manufaktur Di BEI Periode 2009-2012.Fakultas Ekonomi dan Bisnis, Universitas Dian Nuswantoro, Semarang.

Brealey, Myers dan Marcus. (2007). Dasar-Dasar Manajemen Keuangan Perusahaan, Buku Kedua, Erlangga, Jakarta.

Fatimah, Siti. (2015). Analisis Pengaruh Kebijakan Hutang, Investasi, Dividen, terhadap Nilai Perusahaan Food \& Beverages. Jurnal Ilmu dan Riset Manajemen, Vol.4, No.10, Oktober. Sekolah Tinggi Ilmu Ekonomi Indonesia (STIESIA), Surabaya.

Fenandar, Gany Ibrahim dan Raharja, Surya. (2012). Pengaruh Keputusan Investasi, Keputusan Pendanaan, dan Kebijakan Dividen terhadap Nilai Perusahaan. Diponegoro Journal Of Accounting, Vol.1, Nomor 2. Jurusan Akuntansi, Fakultas Ekonomi dan Bisnis Universitas Diponegoro.

Harjito, Agus dan Martono. (2011). Manajemen Keuangan. Ekonisia. Fakultas Ekonomi, Universitas Islam Indonesia Yogyakarta.

Marlina, Lisa dan Danica, Clara. (2009). Analisis Pengaruh Cash Position, Debt To Equity Ratio dan Return On Asset Terhadap Dividen Payout Ratio. Jurnal Manajemen Bisnis, 2 (1): h:1-6

Munawir, S. (2004). Analisa Laporan Keuangan. Yogyakarta. Liberty.

Noviana, Riska. (2016). Pengaruh Keputusan Investasi, Kebijakan Dividen, Kebijakan Hutang, dan Profitabilitas Terhadap Nilai Perusahaan. Skripsi. Program Studi Akuntansi, Fakultas Ekonomi dan Bisnis, Universitas Muhammadiyah Surakarta.

Rahmawati, Apriliana Nuzul dan Haryanto Mulyo. (2012). Analisis Faktor Kebijakan Hutang Yang mempengaruhi Nilai Perusahaan. Jurnal fakultas Ekonomi dan Bisnis, Universitas Diponegoro, Semarang.

Rehulina, Novi Sitepu dan Handoyo C Wibisono. (2014). Pengaruh Kebijakan Dividen, Kebijakan Leverage dan Profitabilitas Terhadap Nilai Perusahaan Manufaktur Yang Terdaftar Di BEI Pada Tahun 2009-2013. Program Studi Manajemen, Fakultas Ekonomi, Universitas Atma Jaya Yogyakarta. 
Septia, AdeWinda. (2015). Pengaruh Profitabilitas Keputusan Investasi, Keputusan Pendanaan, dan Kebijakan Dividen terhadap Nilai Perusahaan Manufaktur Yang Terdaftar Di BEI. Skripsi. Program Studi Manajemen, Fakultas Ekonomi, Universitas Negeri Yogyakarta.

Singgih, Santoso. (2008). Buku Latihan SPSS Parametrik. Jakarta, PT. Alex Komputindo.

Sujoko, Soebiantoro Egy. (2007). Pengaruh Struktur Kepemilikan Saham, Leverage, Faktor Intern dan Faktor Ekstern terhadap Nilai Perusahaan (Studi Empiris Pada Perusahaan Manufaktur dan Non Manufaktur yang Terdaftar Di BEI Jakarta. Jurnal Ekonomi Manajemen, Fakultas Ekonomi, Universitas Kristen Petra. Vol.9, No.1.

Sumantri, Putu Adhy dan Candraningrat, Ica Rika. (2013). Pengaruh Profitabilitas, Firm Size, Likuiditas dan Leverage Terhadap Kebijakan Dividen di BEI. Fakultas Ekonomi, Universitas Bisnis Udayana, Bali.

Sukirni, Dwi. (2012). Kepemilikan Manajerial, Kepemilikan Institusional, Kebijakan Dividen dan Kebijakan Hutang Analisis Terhadap Nilai Perusahaan. Accounting Analysis Journal 2012.

Yuniati, Raharjo, dan Oemar. (2016). Pengaruh Kebijakan Dividen, Kebijakan Hutang,Profitabilitas, dan Struktur Kepemilikan Terhadap Nilai Perusahaan Pada Perusahaan Manufaktur Yang Terdaftar Di BEI Periode 2009-2014. Journal Of Accounting. Vol. 2, No.2, Maret. Fakultas Ekonomika dan Bisnis, Jurusan Akuntansi, Universitas Pandanaran Semarang. 